\title{
The Affect of off-Campus Internships Program on Universities Student's Entrepreneurial Attitude and Capacity
}

\author{
Su-Chang Chen, Hsi-Chi Hsiao, Jen-Chia Chang, and Chun-Mei Chou
}

\begin{abstract}
This paper is to explore the entrepreneurial attitude and capacity of universities' students that could be cultivated and excited through off-campus internships program. A questionnaire-based survey was conducted. There are three types of separate questionnaire, for teachers, students, and business staffs were designed. There were 165 questionnaires delivered to teachers and 620 to students from 31 universities in Taiwan. There were 98 valid questionnaires from teachers were received, representing a valid response rate of $59.39 \%$. There were 370 valid questionnaires from students were returned, representing a valid response rate of $59.67 \%$. There were 60 questionnaires delivered to duty-free stores staffs and 52 valid questionnaires returned, representing a valid response rate of $86.67 \%$. The results show that respondents generally agree that off-campus internships program can cultivate student's entrepreneurial attitude and excite their entrepreneurial capacity. Finally, there are sevel recommendations proposed.
\end{abstract}

Index Terms-Off-campus internship, entrepreneurial capacity, entrepreneurship education, internship education.

\section{INTRODUCTION}

Entrepreneurship can increase a country's wealth and may provide many job opportunities. Entrepreneurship is an excellent strategy to promote economic development and maintain economic competitiveness. In other words, entrepreneurship is an important driver of a country's economic growth, innovation and competitiveness [1]. Many countries regard entrepreneurship education as an approach to solve the societal problem of unemployment. Training and coaching through entrepreneurship courses in schools enhance students' entrepreneurial intentions and entrepreneurial skills [2]. Entrepreneurs should possess certain characteristics, abilities and technology that can be developed through education and training [3]. Universities can play an important role in promoting entrepreneurship [4]. Okudan and Rzasa (2006) pointed out that teaching methods and learning patterns will affect the success or failure of such

Manuscript received March 29, 2016; revised May 19, 2016. We would like to thank the financial support of the Ministry of Science and Technology, Taiwan for the contract number of MOST 102-2511-S-346-001.

Su Chang Chen is with the National Penghu University of Science and Technology, Taiwan (e-mail: csc@gms.npu.edu.tw).

Hsi-Chi Hsiao is with the Cheng Shiu University, Taiwan (e-mail hsichihs@gmail.com).

Jen-Chia Chang is with the National Taipei University of Technology, Taiwan (e-mail: jc5839@ntut.edu.tw).

Chun-Mei Chou is with the National Yunlin University of Science and Technology, Taiwan (e-mail: choucm@yuntech.edu.tw). entrepreneurship education programs [5]. However, Song (2008) analysis of the entrepreneurship programs established by Taiwan university indicated that such programs fail to provide the skills and knowledge that students need, while also lacking traineeship opportunities and community resources [6]. Chen et al. (2014) analysis of the practical-learning semester undertaken by senior students as part of their elective course 'Innovation and Entrepreneurship' at National Penghu University of Science and Technology established that the course did not significantly raise students' entrepreneurial intention, and also found that entrepreneurship could not be taught to students by way of traditional teaching methods [2]. Harkema and Schout (2008) considered that the key points of entrepreneurship lie in teaching methods, teaching environment and learning resources, while entrepreneurship education based on learning-by-doing could strengthen the understanding of the basics knowledge [1], [7]. Off-campus internships program precisely fills this gap, helping students through learning-by-doing in a work environment to deepen the theoretical knowledge they gleaned from school.

Internship programs are an important part of vocational education [8]. Walmsley, Thomas and Jameson (2006) considered that a traineeship experience helped university students better understood the workplace environment and offered them valuable work experience [9]. Ruhanen, Robinson and Breakey (2013) noted that internships, work experience, and the experience of studying while working were key factors enabling students to convert classroom learning to the workplace [10]. Through internship programs, students could learn practical work skills and interpersonal skills, develop an independent spirit, and expand their social experiences, which should be helpful to their career planning [11]. In other words, internship programs enable students to accumulate experience, develop an early understanding of their strengths and weaknesses, and supplement underdeveloped areas in their studies, thus improving their employability or entrepreneurial competences.

This study aims to understand which entrepreneurial attitudes and entrepreneurial capacity possessed by university students can be cultivated and excited through off-campus internship programs.

\section{LITERATURE REVIEW}

A. Entrepreneurial Attitude and Entrepreneurial Capacity Shane and Venkataraman (2000) considered that 
entrepreneurship referred to the entrepreneurial spirit that allowed an entrepreneur to discover, evaluate or create opportunities, with its core value being 'innovation' [12]. Hsiao et al. pointed out that entrepreneurship referred to combining labor, knowledge, technology, management, capital and other production factors, and to use the entrepreneurial spirit to discover, evaluate or create opportunities for productive activities [13], [14]. These would include creating a business from scratch, acquiring distribution or production licenses, acquiring or establishing a business, or inheriting a family business.

"Capacity" is a potential ability or skill. Cherniss (1991) pointed out that capacity is an individual and innate physical gift, the driving force for an individual's growth, which under certain circumstances and backgrounds and through certain methods could be developed and manifested [15]. Chang and Chiu (2012) considered entrepreneurial capacity as a key factor for business success [16]. Chang (2003) suggested that an individual must have entrepreneurial capacity before becoming an entrepreneur, and therefore an entrepreneur must have this entrepreneurial capacity, which includes three key elements [17]:

1) Entrepreneurial drive: the driving force to establish one's own business.

2) Perceived venture feasibility: the ability to perceive the goal of running a business.

3) Propensity to act: personal characteristics of entrepreneurial behavior, including a locus of control, creation, and goal-oriented behavior.

Liñán et al. (2011) pointed out that entrepreneurial capacity should include: the ability to recognize opportunity, creativity, problem-solving skills, leadership skills, communication techniques, the ability to research and develop new services or products, and the ability to grasp the pulse of the market [18]. Zahra and Dess (2001) considered that an individual must possess entrepreneurial capacity prior to become an entrepreneur, regardless of whether this concerns the pursuit of growth in a community or the pursuit of innovation in a large organization [17], [19].

Vazquez et al. (2011) noted that there were five dimensions of an entrepreneurial attitude [20]:

1) Proactiveness: Finding ways to improve in the face of difficulties or changes of events.

2) Responsibility: Willingness to assume the risks of entrepreneurial activity and leading by example.

3) Innovativeness: Ability to predict future needs and trends and to use new methods to solve problems.

4) Independence: Even while constrained in a team, maintaining independent thinking and judgment and making critical decisions.

5) Change Flexibility: In an unstable external environment, knowing how to change an organizational structure and strategic direction.

Chen and Lai (2010) considered that entrepreneurial attitude was a personal conception and evaluation of entrepreneurship and the possession of a propensity to start and operate one's own business [21]. When an individual has a strong inclination to develop a business, the relationship between attitude and behavior will be comparatively strong. The scale that they used includes four dimensions: cognitive, emotional, motivational and behavioral tendencies. Kuckertz and Wagner (2010) used entrepreneurial attitude scale includes these three items [22]:

1) I want to be a boss rather than an employee.

2) Running a business creates wealth.

3) I prefer establishing a new company to being a manager in an existing company.

\section{B. Implications for Internship Education}

Blanchard (2003) said that vocational educational system must serve to demonstrate the abilities of educators to deliver work-ready training converting the youth of today into tomorrow's technology-oriented labor force [23]. The internship program is a link bridge of students' training converted between school and industry. Busby and Fiedel (2001) considered that internship programs could provide students with work experience related to their degree through internships that last for a short period, a semester, a holiday, a year, or even longer [24]. Off-campus internship programs exposed students to extracurricular activities in the real world of work [25]. In other words, traineeships enabled students to have real or practical experience to apply the knowledge learned in the classroom along with the problems and work encountered in a company [26]. Off-campus internship programs could be said to be an important element in cultivating students with competitiveness by linking universities and industry [27]. Therefore, the design of off-campus internship programs must be highly correlated with industry so that students may learn professional knowledge and skills [11]. Lucas et al. (2009) suggested that the host organizations must provide the students with tasks related to the skills they needed for their future careers, as well as feedback on their performance [26].

The planning of an internship program, as well as its immersion in industry, are important factors affecting whether or not graduates will stay in the industry. Lucas et al. (2009) found that British students returned to school from their traineeship sites had more self-confidence and a better understood of business and technology [26]. In a survey of 307 students from four universities in Hong Kong, Lam and Chin (2007) found three expectations held by students before their traineeships: expanding their work experience, developing technical skills, and having the opportunity to join the host company as an employee [28]. In an investigation of the marketing and logistics-related departments of 21 vocational institutions in Taiwan, Chen et al. (2014) found that three schools $(14.3 \%)$ indicated that their school had teaching materials for their off-campus traineeship programs, while 18 schools $(85.7 \%)$ did not, and that therefore teaching materials for off-campus traineeship programs seemed to be needed at all schools in Taiwan [29]. Lucas et al. (2009) survey of 256 junior and senior students from four universities in the UK found that $45.1 \%$ of students think that traineeships teach something that they could not learn in courses at school, and that this confirmed the importance of internship [26].

\section{Off-campus Internship Programs with an Entrepreneurial Orientation}

Traineeship experiences benefit students in their academic or work-related environments through the acquisition of skills 
and vocational qualities. In off-campus internship programs, students absorb work experience in a company, gained practical experience. Through the traineeship process, students may develop initiative, independence, and acquire a solid work ethic and thinking ability [30]. Therefore, off-campus internship programs may enhance student competences that are related to entrepreneurship and develop the personality traits of an entrepreneur. Keat et al. (2011) indicated that entrepreneurship education should not be confined to classroom discussion, but should instead engage with the external environment [4]. Only through practice could be developed important entrepreneurial skills, and only through observing, experiencing and feeling the business world could make students obtain real work experience. Karimi et al. (2010) emphasized that entrepreneurship education must include the following: teaching students how to identify market opportunities and commercial thinking to establish a new business in order to seize market opportunities; teaching students how to configure and leverage resources needed to pursue business opportunities; and educating students how to create, manage and operate a commercial organization. These items should be the basis of planning the curriculum of an entrepreneurship-oriented off-campus internship programs [31]. Therefore, Hiltebeitel, Leauby and Larkin (2000) recommends that entrepreneurship education should regard internship programs as an important element [32]. Papaoikonomou, Segarra and Li (2012) pointed out that enterprises should establish appropriate infrastructure and training centers as a good way to encourage and support entrepreneurial activity and provide traineeship opportunities for students [33].

Soysekerci and Erturgut (2010) indicated that students' traineeship processes in NGO's could allow them to apply elements from their internship to entrepreneurial activities [34]. Thus, Beggs et al. (2008) recommended that during student's traineeships should review their own career development [7]. It also gave them the opportunity to feel the tension and complexity of the workplace, to enhance their innovation and competitiveness by getting their hands dirty, and to have the opportunity to verify theory through practice. Wong, Ho and Singh (2007) pointed out that in Singaporean university curriculums there had a mechanism for their students to do one-year internship programs at overseas companies, and students may also attend entrepreneurship courses at sister universities [35]. So, they could immerse themselves in the entrepreneurship experience within a company. However, they still lack a structure for off-campus internship programs that enhanced their entrepreneurial spirit and ability. If it was without these off-campus internship programs, students may not develop the entrepreneurial mindset and skill set needed. Likewise, Erikson (2002) mentioned that students' need for traineeships and entrepreneurial training to strengthen their entrepreneurial skills and perception [36]. In order to help students establish businesses, universities should provide students with coaching, consulting, training and other support services.

Therefore, internship programs may be regarded as one tool of entrepreneurship education, to help students observe business opportunities and bolster their entrepreneurial ambitions during their traineeships period.

\section{RESEARCH METHODS}

\section{A. Research Framework}

The research framework is shown in Fig. 1. This study tries to understand which entrepreneurial attitudes and entrepreneurial capacity possessed by university students can be cultivated and excited through off-campus internship programs.

The hypotheses $\mathrm{H} 1$ is that there is significant difference among teachers, students and business staffs in entrepreneurial attitude

The hypothesis $\mathrm{H} 2$ is that there is significant difference among teachers, students and business staffs in entrepreneurial capacity.

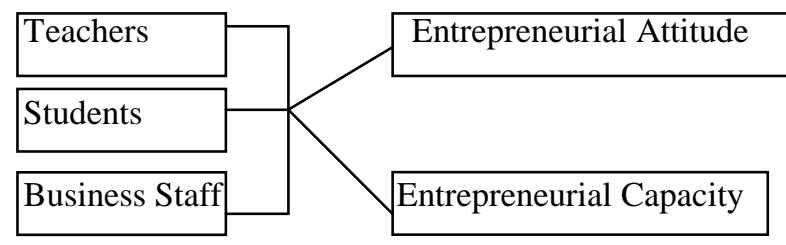

Fig. 1. Research framework.

\section{B. Measurement Instrument}

For entrepreneurial attitude, the scale of Vazquez et al. (2011) was used [20], with a total of 30 items. Among these, eight items relate to "proactiveness", with a Cronbach's Alpha value of 0.882 . Four items relate to "independence", with a Cronbach's Alpha value of 0.834. Five items relate to "innovativeness", with a Cronbach's Alpha value of 0.871 . Seven items relate to "change flexibility", with a Cronbach's Alpha value of 0.835 . Six items relate to "responsibility", with a Cronbach's Alpha value of 0.850. The overall Cronbach's Alpha value for all scale was 0.962. The total reliability is acceptable.

The measurement instrument for students' entrepreneurial capacity that can be excited is a scale by Chang and Chiu (2012) [16], adapted from Liñán et al. (2011) [18]. This scale consists of 6 items, with a Cronbach's Alpha value of 0.907 . The reliability is acceptable.

The questionnaires were self-report inventory. Both scales use a 7-point Likert type scale, from strongly agree (7) to strongly disagree (1). The higher the score is, the higher the student's entrepreneurial capacity and entrepreneurial attitudes that can be cultivated and excited through an off-campus internship programs are. This study was conducted with separate questionnaires designed to avoid common method variance.

\section{Implementation Process}

This study was conducted by way of a questionnaire-based survey, with separate questionnaires designed for teachers, students, and host business staff. The sampling method employed was a convenient and non-probability sampling approach. The questionnaires were distributed by the marketing and logistics department chairperson of the participating universities. The questionnaires were delivered to 4 teachers who had experience with supervising students in internship programs and to 20 students who had traineeship experience. The survey was distributed to 31 technical 
universities, of which 21 universities returned. 98 valid questionnaires were collected from teachers, 21 of which were from department chairperson and 77 from teachers. It represented a valid response rate of $59.39 \%$. 370 questionnaires were collected from students, representing a valid response rate of $59.67 \%$.

TABLE I: THE CHARACTERISTICS OF SAMPLES

\begin{tabular}{|c|c|c|c|c|}
\hline Identity & Category & Classification & Frequency & Percentage \\
\hline \multirow{15}{*}{$\begin{array}{l}\text { Teach } \\
\text { ers(98) }\end{array}$} & \multirow[t]{2}{*}{ Gender } & Male & 62 & $63.3 \%$ \\
\hline & & Female & 36 & $36.7 \%$ \\
\hline & \multirow{2}{*}{$\begin{array}{l}\text { Schools } \\
\text { nature }\end{array}$} & Public school & 14 & $14.3 \%$ \\
\hline & & Private school & 84 & $85.7 \%$ \\
\hline & \multirow[t]{2}{*}{ School level } & $\begin{array}{l}\text { Technical } \\
\text { university }\end{array}$ & 80 & $81.6 \%$ \\
\hline & & $\begin{array}{l}\text { Technical } \\
\text { institute }\end{array}$ & 18 & $18.4 \%$ \\
\hline & \multirow[t]{2}{*}{ Title } & $\begin{array}{l}\text { Department } \\
\text { chairperson }\end{array}$ & 21 & $21.4 \%$ \\
\hline & & Teacher & 77 & $88.6 \%$ \\
\hline & \multirow{4}{*}{$\begin{array}{l}\text { Professor } \\
\text { level }\end{array}$} & Professor & 10 & $10.2 \%$ \\
\hline & & $\begin{array}{l}\text { Associate } \\
\text { professor }\end{array}$ & 27 & $27.6 \%$ \\
\hline & & $\begin{array}{l}\text { Assistant } \\
\text { professor }\end{array}$ & 45 & $45.9 \%$ \\
\hline & & Instructor & 16 & $16.3 \%$ \\
\hline & \multirow{3}{*}{$\begin{array}{l}\text { Teaching } \\
\text { experience }\end{array}$} & Below 5 years & 10 & $10.2 \%$ \\
\hline & & $\begin{array}{l}\text { Between } 5 \text { to } \\
10 \text { years }\end{array}$ & 22 & $22.5 \%$ \\
\hline & & $\begin{array}{ll}\begin{array}{l}\text { Above } \\
\text { years }\end{array} & 10 \\
\end{array}$ & 66 & $67.3 \%$ \\
\hline \multirow{14}{*}{$\begin{array}{l}\text { Studen } \\
\text { ts(370) }\end{array}$} & \multirow[t]{2}{*}{ Gender } & Male & 134 & $36.2 \%$ \\
\hline & & Female & 236 & $63.8 \%$ \\
\hline & \multirow{2}{*}{$\begin{array}{l}\text { Schools } \\
\text { nature }\end{array}$} & Public school & 62 & $16.8 \%$ \\
\hline & & Private school & 308 & $83.2 \%$ \\
\hline & \multirow[t]{2}{*}{ School level } & $\begin{array}{l}\text { Technical } \\
\text { university }\end{array}$ & 309 & $83.5 \%$ \\
\hline & & $\begin{array}{l}\text { Technical } \\
\text { institute }\end{array}$ & 61 & $16.5 \%$ \\
\hline & \multirow[t]{3}{*}{$\begin{array}{l}\text { Type of } \\
\text { internship }\end{array}$} & $\begin{array}{l}\text { Summer/Wint } \\
\text { er vacation }\end{array}$ & 157 & $42.4 \%$ \\
\hline & & One semester & 80 & $21.6 \%$ \\
\hline & & $\begin{array}{l}\text { One academic } \\
\text { year }\end{array}$ & 133 & $36.0 \%$ \\
\hline & \multirow[t]{3}{*}{ Grade } & Sophomore & 42 & $11.4 \%$ \\
\hline & & Junior & 47 & $12.7 \%$ \\
\hline & & Seniors & 281 & $75.9 \%$ \\
\hline & \multirow{2}{*}{$\begin{array}{l}\text { Parents have } \\
\text { entrepreneuri } \\
\text { al experience }\end{array}$} & Yes & 144 & $38.9 \%$ \\
\hline & & No & 226 & $61.1 \%$ \\
\hline \multirow{8}{*}{$\begin{array}{l}\text { Busine } \\
\text { ss } \\
\text { staffs } \\
(52)\end{array}$} & \multirow[t]{2}{*}{ Gender } & Male & 18 & $34.6 \%$ \\
\hline & & Female & 34 & $65.4 \%$ \\
\hline & \multirow[t]{2}{*}{ Position } & $\begin{array}{l}\text { Executive } \\
\text { positions }\end{array}$ & 16 & $30.8 \%$ \\
\hline & & $\begin{array}{l}\text { Non-executiv } \\
\text { e positions }\end{array}$ & 36 & $69.2 \%$ \\
\hline & \multirow[t]{2}{*}{ Department } & Sales & 37 & $71.2 \%$ \\
\hline & & Administration & 15 & $18.8 \%$ \\
\hline & \multirow{2}{*}{$\begin{array}{l}\text { Work } \\
\text { experience }\end{array}$} & Below 3 years & 37 & $71.2 \%$ \\
\hline & & Above 3 years & 15 & $18.8 \%$ \\
\hline
\end{tabular}

The host business staffs were employed by a duty-free store, where trainees receive one week of workshops and training prior to the internship. During the internship period, trainees participate in a rotation system, while school counselors will visit the workplace and hold talks with the relevant departments to monitor the students' traineeships. The manager of this duty-free store distributed the questionnaires to staffs that were in contact with trainees. A total of 60 questionnaires were distributed, of which 52 valid questionnaires were returned. It represented a valid response rate of $86.67 \%$.

\section{Sample Characteristics}

There were 98 teachers, 370 students and 52 business staffs returned their questionnaires for this study. It sample characteristics are shown in Table I.

In the teacher's part, there were 62 male teachers $(63.3 \%)$, 36 female $(36.7 \%)$; there were 14 teachers $(14.3 \%)$ work in public school, and 84 teachers $(85.7 \%)$ work in private school; there were 80 teachers $(85.7 \%)$ work in technical university, and 18 teachers $(18.4 \%)$ work in technical institute; there were 21 department chairperson $(21.4 \%)$ return their questionnaires, the others were only teachers; there were 10 professors (10.2\%), 27 associate professors (27.6\%), 45 assistant professors (45.9\%), and 16 instructors (16.3\%) participated this survey. Among them, there were 10 teachers (10.2\%) teaching experience below 5 years, 22 teachers $(22.5 \%)$ teaching experience between 5 years to 10 years, and 66 teachers $(67.3 \%)$ teaching experience more than 10 years.

In the student's part, there were 134 male students (36.2\%), 236 female students (63.8\%); there were 62 students (16.8\%) study in public school, and 308 students (83.2\%) study in private school; there were 309 students $(83.5 \%)$ study in technical university, and 61 students (16.5\%) work in technical institute. Among them, there were 157 students (42.4\%) engaged their internship programs in summer/winter vacation, 80 students $(21.6 \%)$ study in one semester, and 133 students(36.0\%) used one academic year in off-campus internship programs; there were 42 sophomore students (11.4\%), 47 junior students $(12.7 \%)$, and 281 senior students (75.9\%); there were 144 students' parents had entrepreneurial experience (38.9\%), 226 students' parents not $(61.1 \%)$.

In the business staff's part, there were 18 male staffs (34.6\%), 34 female staffs $(65.4 \%)$; there were 16 executive position staffs $(30.8 \%)$, and 36 non-executive position staffs $(69.2 \%)$; there were 37 staffs $(71.2 \%)$ work in sales department, and 15 staffs $(18.8 \%)$ work in administration department; there were 37 staffs $(71.2 \%)$ work experience below 3 years, and 15 staffs $(18.8 \%)$ work experience more than 3 years.

\section{RESULTS}

\section{A. Entrepreneurial Attitude}

According to the average, the "innovativeness" (M=5.31, $\mathrm{SD}=0.90)$ is the highest, followed by "independence" $(\mathrm{M}=5.24, \quad \mathrm{SD}=0.96), \quad$ "change flexibility" $\quad(\mathrm{M}=5.19$, $\mathrm{SD}=0.82)$," "proactiveness" $(\mathrm{M}=5.07, \mathrm{SD}=0.88)$, and the lowest is "responsibility" $(\mathrm{M}=5.02, \quad \mathrm{SD}=0.91)$. All dimensions are more than 4 , it means that all subject agreed that through off-campus internship programs can cultivate student's entrepreneurial attitude. It is shown in Table II.

From individual respondents opinions, the "innovativeness" $(\mathrm{M}=5.18, \mathrm{SD}=1.04)$ is the highest for teachers, followed by "independence" $(\mathrm{M}=5.13, \mathrm{SD}=1.11)$, "change flexibility" (M=4.98, $\mathrm{SD}=0.94)$, "proactiveness" $(\mathrm{M}=4.89, \mathrm{SD}=0.97)$, and the lowest is "responsibility" $(\mathrm{M}=4.68, \mathrm{SD}=1.02)$. For students, the "innovativeness" $(\mathrm{M}=5.34, \quad \mathrm{SD}=0.86)$ is the highest, followed by 
"independence" ( $\mathrm{M}=5.25, \mathrm{SD}=0.92)$, "change flexibility" $(\mathrm{M}=5.23, \mathrm{SD}=0.79)$, "responsibility" $(\mathrm{M}=5.10, \mathrm{SD}=0.87)$, and the lowest is "proactiveness" $(\mathrm{M}=5.09, \mathrm{SD}=0.85)$. The rank is little different with teachers opinions. For business staffs, the "innovativeness" $(\mathrm{M}=5.38, \mathrm{SD}=0.90)$ is the highest, followed by "independence" $(\mathrm{M}=5.35, \quad \mathrm{SD}=0.92)$ "proactiveness" (M=5.31, $\mathrm{SD}=0.81)$, "change flexibility" $(\mathrm{M}=5.29, \mathrm{SD}=0.78)$, and the lowest is "responsibility" $(\mathrm{M}=5.13, \mathrm{SD}=0.91)$. The rank is little different with teachers and students.

TABLE II: ANOVA ANALYSIS FOR ENTREPRENEURIAL ATTITUDE

\begin{tabular}{|c|c|c|c|c|c|c|c|}
\hline Dimension & Identity & Frequency & Mean & S.D & $\mathrm{F}$ & $\mathrm{P}$ & Scheffe \\
\hline \multirow[t]{4}{*}{ Proactiveness } & Teacher & 98 & 4.89 & 0.97 & \multirow[t]{4}{*}{$4.217^{*}$} & \multirow[t]{4}{*}{.015} & \multirow[t]{4}{*}{$\mathrm{B}>\mathrm{T}$} \\
\hline & Students & 370 & 5.09 & 0.85 & & & \\
\hline & Business Staff & 52 & 5.31 & 0.81 & & & \\
\hline & Total & 520 & 5.07 & 0.88 & & & \\
\hline \multirow[t]{4}{*}{ Independence } & Teacher & 98 & 5.13 & 1.11 & \multirow[t]{4}{*}{.982} & \multirow[t]{4}{*}{.375} & \\
\hline & Students & 370 & 5.25 & 0.92 & & & \\
\hline & Business Staff & 52 & 5.35 & 0.92 & & & \\
\hline & Total & 520 & 5.24 & 0.96 & & & \\
\hline \multirow[t]{4}{*}{ Innovativeness } & Teacher & 98 & 5.18 & 1.04 & \multirow[t]{4}{*}{1.464} & \multirow[t]{4}{*}{.232} & \\
\hline & Students & 370 & 5.34 & 0.86 & & & \\
\hline & Business Staff & 52 & 5.38 & 0.90 & & & \\
\hline & Total & 520 & 5.31 & 0.90 & & & \\
\hline \multirow[t]{4}{*}{ Change Flexibility } & Teacher & 98 & 4.98 & 0.94 & \multirow[t]{4}{*}{$3.984 *$} & \multirow[t]{4}{*}{.019} & \multirow{4}{*}{$\begin{array}{l}\mathrm{S}>\mathrm{T} \\
\mathrm{B}>\mathrm{T}\end{array}$} \\
\hline & Students & 370 & 5.23 & 0.79 & & & \\
\hline & Business Staff & 52 & 5.29 & 0.78 & & & \\
\hline & Total & 520 & 5.19 & 0.82 & & & \\
\hline \multirow[t]{4}{*}{ Responsibility } & Teacher & 98 & 4.68 & 1.02 & \multirow[t]{4}{*}{$8.657 * * *$} & \multirow[t]{4}{*}{.000} & \multirow{4}{*}{$\begin{array}{l}S>T \\
B>T\end{array}$} \\
\hline & Students & 370 & 5.10 & 0.87 & & & \\
\hline & Business Staff & 52 & 5.13 & 0.84 & & & \\
\hline & Total & 520 & 5.02 & 0.91 & & & \\
\hline
\end{tabular}

$* p<0.05, * * p<0.01, * * * p<0.001$

TABLE III: ANOVA ANALYSIS FOR ENTREPRENEURIAL CAPACITY

\begin{tabular}{|c|c|c|c|c|c|c|c|}
\hline $\begin{array}{l}\text { Entrepreneurial capacity } \\
\text { items }\end{array}$ & Identity & Frequency & Mean & S.D & $\mathrm{F}$ & $\mathrm{P}$ & Scheffe \\
\hline \multirow{4}{*}{$\begin{array}{l}\text { The ability to identify } \\
\text { opportunities }\end{array}$} & Teacher & 98 & 5.08 & 1.34 & \multirow[t]{4}{*}{1.302} & \multirow[t]{4}{*}{.273} & \\
\hline & Students & 370 & 5.12 & 1.14 & & & \\
\hline & Business Staff & 52 & 5.38 & 1.11 & & & \\
\hline & Total & 520 & 5.14 & 1.18 & & & \\
\hline \multirow[t]{4}{*}{ Creativity } & Teacher & 98 & 4.92 & 1.42 & \multirow[t]{4}{*}{1.763} & \multirow[t]{4}{*}{.172} & \\
\hline & Students & 370 & 5.18 & 1.15 & & & \\
\hline & Business Staff & 52 & 5.12 & 1.17 & & & \\
\hline & Total & 520 & 5.12 & 1.21 & & & \\
\hline \multirow[t]{4}{*}{ Problem-solving skills } & Teacher & 98 & 5.47 & 1.35 & \multirow[t]{4}{*}{.054} & \multirow[t]{4}{*}{.948} & \\
\hline & Students & 370 & 5.43 & 1.08 & & & \\
\hline & Business Staff & 52 & 5.44 & 1.20 & & & \\
\hline & Total & 520 & 5.44 & 1.14 & & & \\
\hline \multirow[t]{4}{*}{ Leadership } & Teacher & 98 & 4.95 & 1.38 & \multirow[t]{4}{*}{$5.692 * *$} & \multirow[t]{4}{*}{.004} & \multirow[t]{4}{*}{$\mathrm{S}>\mathrm{T}$} \\
\hline & Students & 370 & 5.40 & 1.12 & & & \\
\hline & Business Staff & 52 & 5.33 & 1.25 & & & \\
\hline & Total & 520 & 5.31 & 1.20 & & & \\
\hline \multirow{4}{*}{$\begin{array}{l}\text { The ability to develop new } \\
\text { services/ products }\end{array}$} & Teacher & 98 & 4.54 & 1.45 & \multirow[t]{4}{*}{$5.016^{* *}$} & \multirow[t]{4}{*}{.007} & \multirow[t]{4}{*}{$\mathrm{S}>\mathrm{T}$} \\
\hline & Students & 370 & 4.97 & 1.17 & & & \\
\hline & Business Staff & 52 & 5.00 & 1.12 & & & \\
\hline & Total & 520 & 4.89 & 1.23 & & & \\
\hline \multirow{4}{*}{$\begin{array}{l}\text { The ability to grasp the } \\
\text { pulse of the market's }\end{array}$} & Teacher & 98 & 5.01 & 1.45 & \multirow[t]{4}{*}{.321} & \multirow[t]{4}{*}{.726} & \\
\hline & Students & 370 & 5.04 & 1.22 & & & \\
\hline & Business Staff & 52 & 5.17 & 1.10 & & & \\
\hline & Total & 520 & 5.04 & 1.25 & & & \\
\hline \multirow[t]{4}{*}{ Entrepreneurial capacity } & Teacher & 98 & 4.99 & 1.24 & \multirow[t]{4}{*}{1.681} & \multirow[t]{4}{*}{.187} & \\
\hline & Students & 370 & 5.19 & 0.92 & & & \\
\hline & Business Staff & 52 & 5.24 & 0.99 & & & \\
\hline & Total & 520 & 5.16 & 0.99 & & & \\
\hline
\end{tabular}

$* p<0.05, * * p<0.01, * * * p<0.001$

In ANOVA analysis, in proactiveness, change flexibility, responsibility three dimensions are significant difference among teachers, students and business staffs. H1 is acceptable. After Scheffe's method analysis, business staffs are strongly agreed that through off-campus internship programs can cultivate student's proactiveness, change flexibility, responsibility than teachers. Students are strongly agreed that through off-campus internship programs can cultivate student's change flexibility, responsibility than teachers.

\section{B. Entrepreneurial Capacity}

In Table III, it shows that entrepreneurial capacity $(\mathrm{M}=$ $5.20, \mathrm{SD}=0.99$ ) is greater than 4. This represents all respondents agreed that through off-campus internship 
programs can excite student's entrepreneurial capacity. According to the average, the "problem-solving skills" ( $\mathrm{M}=$ $5.44, \mathrm{SD}=1.14)$ is the highest, followed by "leadership" $(\mathrm{M}=$ $5.31, \mathrm{SD}=1.20)$, "the ability to identify opportunities" $(\mathrm{M}=$ $5.14, \mathrm{SD}=1.18)$, "creativity" $(\mathrm{M}=5.12, \mathrm{SD}=1.17)$, "the ability to grasp the pulse of the market's" $(\mathrm{M}=5.04, \mathrm{SD}=$ $1.25)$, and the lowest is "the ability to develop new services / products " $(\mathrm{M}=4.89, \mathrm{SD}=1.23)$. These all individual items are more than 4 , it means that all respondents agreed that through off-campus internship programs can excite student's entrepreneurial capacity.

From individual respondents opinions, according to the average, the "problem-solving skills" $(\mathrm{M}=5.47, \mathrm{SD}=1.35)$ is the highest for teachers, followed by "the ability to identify opportunities" $(\mathrm{M}=5.08, \mathrm{SD}=1.34)$, "the ability to grasp the pulse of the market's" (M = 5.01, $\mathrm{SD}=1.45)$, "leadership" (M $=4.95, \mathrm{SD}=1.38)$, "creativity" $(\mathrm{M}=4.92, \mathrm{SD}=1.42)$, and the lowest is "the ability to develop new services / products " $(\mathrm{M}=$ $4.54, \mathrm{SD}=1.45)$. For students, the "problem-solving skills" $(\mathrm{M}=5.43, \mathrm{SD}=1.08)$ is the highest, followed by "leadership" $(\mathrm{M}=5.40, \mathrm{SD}=1.12)$, , "creativity" $(\mathrm{M}=5.18, \mathrm{SD}=1.15)$ "the ability to identify opportunities" $(\mathrm{M}=5.12, \mathrm{SD}=1.14)$, "the ability to grasp the pulse of the market's" (M = 5.04, SD = $1.22)$, and the lowest is "the ability to develop new services / products " $(\mathrm{M}=4.97, \mathrm{SD}=1.17)$. The rank is little different with teachers opinions. For business staffs, the "problem-solving skills" ( $\mathrm{M}=5.44, \mathrm{SD}=1.20)$ is the highest, followed by , "the ability to identify opportunities" ( $\mathrm{M}=5.38$, $\mathrm{SD}=1.11)$, "leadership" $(\mathrm{M}=5.33, \mathrm{SD}=1.25)$, "the ability to grasp the pulse of the market's" ( $\mathrm{M}=5.17, \mathrm{SD}=1.10)$, "creativity" ( $\mathrm{M}=5.12, \mathrm{SD}=1.17)$, and the lowest is "the ability to develop new services / products "( $\mathrm{M}=5.00, \mathrm{SD}=$ 1.12). The rank is little different with teachers and students.

In ANOVA analysis, there is no significant difference among teachers, students and business staffs in entrepreneurial capacity, but in leadership, develop new services/ products ability two items are significant difference. $\mathrm{H} 2$ is partial acceptable. After Scheffe's method analysis, students are strongly agreed that through off-campus internship programs can excite student's leadership, develop new services/ products ability than teachers.

\section{CONCLUSIONS AND DISCUSSION}

Results from the questionnaires and interviews, the first conclusion of this study is that off-campus internship programs can cultivate student's entrepreneurial attitude and excite their entrepreneurial capacity.

Secondly, the rank of entrepreneurial attitude dimensions, entrepreneurial capacity items are little different among teachers, students and business staffs.

Thirdly, proactiveness, change flexibility, responsibility three dimensions are significant difference among teachers, students and business staffs. After Scheffe's method analysis, business staffs are strongly agreed that through off-campus internship programs can cultivate student's proactiveness, change flexibility, responsibility than teachers. Students are strongly agreed that through off-campus internship programs can cultivate student's change flexibility, responsibility attitude than teachers.

Lastly, there is no significant difference among teachers, students and business staffs in entrepreneurial capacity, but in leadership, develop new services/ products ability two items are significant difference. After Scheffe's method analysis, students are strongly agreed that through off-campus internship programs can excite their leadership, develop new services/ products ability than teachers.

There are sevel recommendations of the study. First, an entrepreneurship-oriented design of off-campus internship programs is worth considering for entrepreneurship educators who want to release and strengthen students' entrepreneurial attitude and entrepreneurial capacity through off-campus traineeship programs.

Secondly, it can establish FACEBOOK groups or LINE groups for students during their off-campus traineeships. Here, an issue-oriented approach may give students the opportunity to engage in group discussions on such topics as: What leadership behaviors of the traineeship supervisor are worth learning? How do employees in the host organization solve problems they encounter? How does the host organization seize market changes? Have you found business opportunities through your internship experience? What innovation practices does your host organization have that are worth learning? Through interviews with entrepreneurs, business owners, and managers, company brochures, executive biographies, internal documents and analyses, as well as other channels, students may observe and acquire information. This may improve the effectiveness of student internship and strengthen students' entrepreneurial attitude and entrepreneurial capacity.

Thirdly, this study only discusses entrepreneurial attitude and entrepreneurial capacity, it can increase study entrepreneurial intention and to probe the relationship among entrepreneurial attitude, entrepreneurial capacity, and entrepreneurial intention.

Lastly, this study only focus on duty-free shops staffs. When inference to other industries will be limited, it is recommended to survey different industries and to compared with this study.

\section{REFERENCES}

[1] S. J. M. Harkema and H. Schout, "Incorporating student-centred learning in innovation and entrepreneurship education," European Journal of Education, vol. 43, no. 4, pp. 513-526, 2008.

[2] S. C. Chen, H. C. Hsiao, J. C. Chang, C. M. Chou, C. P. Chen, and C. H. Shen, "Can the entrepreneurship course improve the entrepreneurial intentions of students?" International Entrepreneurship and Management Journal, vol. 11, no. 3, pp. 557-569, 2015.

[3] T. V. Menzies and J. C. Paradi, "Entrepreneurship education and engineering students: Career path and business performance," International Journal of Entrepreneurship and Innovation, vol. 6, no. 2, pp. 85-96, 2003.

[4] O. Y .Keat, C. Selvarajah, and D. Meyer, "Inclination towards entrepreneurship among university students: An empirical study of Malaysian university students," International Journal of Business and Social Science, vol. 2, no. 4, pp. 206-220, 2011.

[5] G. E. Okudan and S. E. Rzasa, "A project-based approach to entrepreneurial leadership education," Technovation, no. 26, pp. 195-210, 2006.

[6] Q. L. Song, "Taiwan entrepreneurship courses exploration - A comparative perspective," Jinwen University Journal of Foreign Languages, no. 8, pp. 84-103, 2008.

[7] B. Beggs, C. M. Ross, and B. Goodwin, "A comparison of student and practitioner perspective of the travel and tourism internship," 
Journal of Hospitality, Leisure, Sport and Tourism Education, vol. 7, no. 1, pp. 31-39, 2008.

[8] V. Gamboa, M. P. Paixão, and S. N. Jesus, "Internship quality predicts career exploration of high school students," Journal of Vocational Behavior, no. 82, pp. 78-87, 2013.

[9] A. Walmsley, R. Thomas, and S. Jameson, "Surprise and sense-making: Undergraduate placement experiences in SMEs," Education+Training, no. 48, pp. 360-372, 2006.

[10] L. Ruhanen, R. Robinson, and N. Breakey, "A foreign assignment: Internships and international students," Journal of Hospitality and Tourism Management, no. 20, pp. 1-4, 2013.

[11] M. Aggett , and G. Busby, "Opting out of internship: Perceptions of hospitality, tourism and events management undergraduates at a British University," Journal of Hospitality, Leisure, Sport and Tourism Education, vol. 10, no. 1, pp. 106-113, 2011.

[12] S. Shane and S. Venkataraman, "The promise of entrepreneurship as a field of research," Academy of Management Review, vol. 10, no. 5, pp. $217-226,2000$

[13] H. C. Hsiao et al., "Developing and evaluating teaching material for entrepreneurship management course," presented at 2012 Exploring Leadership and Learning Theories in Asia International Conference, Malaysia: Langkawi, 2012.

[14] H. C. Hsiao, S. C. Chen, J. C. Chang, C. M. Chou, C. P. Chen, and C. H. Shen, "The entrepreneurial competences for starting a store," Advances in Information Sciences and Service Sciences, vol. 4, no. 11, pp. 76-83, 2012.

[15] C. Cherniss, "Long-term consequences of burnout: An exploratory study," Journal of Organizational Behavior, no. 12, pp. 1-11, 1991

[16] J. C. Chang and P. J. Chiu, "Are you ready for venturing? College student's entrepreneurial motivation and entrepreneurial capability," Crown Journal of Business Management, vol. 2, no. 2, pp. 17-25, 2012.

[17] S. H. Chang, "The Construction of entrepreneurial potential model and the application in entrepreneurial education (I)," National Science Council of Taiwan project number: NSC91-2516-S212-002, 2003.

[18] F. Liñán, J. C. Rodríguez-Cohard, and J. M. Rueda-Cantuche, "Factors affecting entrepreneurial intention levels: a role for education," International Entrepreneurship and Management Journal, vol. 7, no. 2, pp. 195-218, 2011

[19] S. Zahra and G. Dess, "Entrepreneurship as a field of research: Encouraging dialogue and debate," Academy of Management Review. no. 26, pp. 8-10, 2011.

[20] J. L. Vazquez, A. Lanero et al., "Fostering entrepreneurship at the university: a Spanish empirical study," Transylvanian Review of Administrative Sciences, no. 32, pp. 252-276, 2011.

[21] Y. F. Chen and M. C. Lai, "Factors influence the entrepreneurial attitude of Taiwanese tertiary-level business student," Social Behavior and Personality, vol. 38, no. 1, pp. 1-12, 2010.

[22] A. Kuckertz and M. Wagner, "The influence of sustainability orientation on entrepreneurial intentions - Investigating the role of business experience," Journal of Business Venturing, no. 25, pp. 524-539, 2010.

[23] W. R. Blanchard, "Wiring student certifications to industry careers," Techniques, vol. 75, no. 8, p. 26, 2003.

[24] G. Busby and D. Fiedel, "A contemporary review of degrees in the United Kingdom," Journal of Vocational Education and Training, no. 53 , pp. 501-522, 2001

[25] N. T. Neill and G. E. Mulholland, "Student placement-structure, skills and e-support," Education+Training, vol. 45, no. 2, pp. 89-99, 2003.

[26] W. A. Lucas, S. Y. Cooper, T. Ward, and F. Cave, "Industry placement, authentic experience and the development of venturing and technology self-efficacy," Technovation, no. 29, 738-752, 2009.

[27] F. Alpert, J. G. Heaney, and K. A. L. Kuhn, "Internships in marketing: Goals, structures and assessment - Student, company and academic perspectives," Australasian Marketing Journal, no. 17, pp. 36-45, 2009.

[28] T. Lam and L. Ching, "An exploratory study of an internship program: The case of Hong Kong students," Hospitality Management, no. 26, pp 336-351, 2007.

[29] S. C. Chen, H. C. Hsiao, and J. C. Chang, "What entrepreneurial competences can be learned through off-campus internship program?" presented at the Eighteenth Global Chinese Conference on Computer in Education, China: Shanghai, 2014.

[30] L. Emma, "The public relations internship experience: A comparison of student and site supervisor perspectives," Public Relations Review, vol. 10 , no. 5, pp. 37, 470-477, 2011

[31] S. Karimi, M. Chizari, H. J. A. Biemans, and M. Mulder "Entrepreneurship education in Iranian higher education: The curren state and challenges," European Journal of Scientific Research, vol. 48 , no. 1 , pp. $35-50,2010$

[32] K. M. Hiltebeitel, B. A. Leauby, and J. M. Larkin, "Job satisfaction among entry-level accountants," The CPA Journal, vol. 70, no. 5, pp $76-78,2000$.

[33] E. Papaoikonomou, P. Segarra, and X. Li, "Entrepreneurship in the context of Crisis: Identifying barriers and proposing strategies," International Advance Econimal Research, no. 18, pp. 111-119, 2012

[34] S. Soysekerci and R. Erturgut, "Improvement of non-governmental organization entrepreneurship in vocational schools: Turkey case," Procedia Social and Behavioral Sciences, no. 2, pp. 1849-1854, 2010

[35] P. K. Wong, Y. P. Ho, and A. Singh, "Towards an entrepreneuria university model to support knowledge-based economic development: The case of the National University of Singapore," World Development, vol. 35, no. 6, pp. 941-958, 2007.

[36] T. Erikson, "Entrepreneurial capital: The emerging venture's most important asset and competitive advantage," Journal of Busines. Venturing, no. 17, pp. 275-290, 2002.

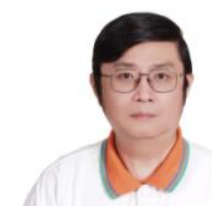

Su-Chang Chen is a professor \& chair at the Department of Marketing and Logistics Management in National Penghu University. He gained the MBA degree from Institute of Managemnet Science in National Chia-Tung University in 1972 and the $\mathrm{PhD}$ degree from the Department of Industrial Education in National Changhua University of Education in 1999. His research interests include vocational and technological education, human resource management, and business administration.

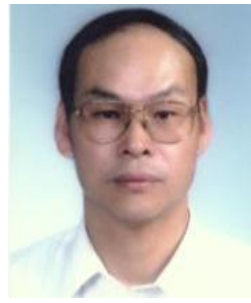

Hsi-Chi Hsiao received his M.S. degree from University of Wisconsin in 1983 and the Ph.D. from Indiana State University in 1987. He was the head of the Department of Industrial Education at National Changhua University of Education and president of National Penghu Institute of Technology in Taiwan. $\mathrm{He}$ has also served as government consultant in the field of curriculum and instruction, vocational and technological education, research in applied science education for many years. He is now a chair professor at Graduate Institute of Business and Administration, Cheng Shiu University.

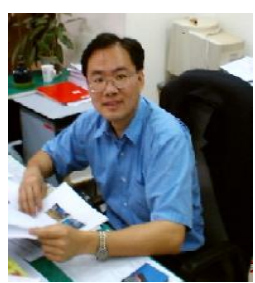

Jen-Chia Chang gained a BEd in industria education in 1991 from National Taiwan Normal University, an MA in industrial education in 1994 from National Changhua University of Education, and $\mathrm{a} \mathrm{PhD}$ in industrial education in 1999 from National Changhua University of Education. Currently, he is a professor in Institute of Vocational and Technological Education, National Taipe University of Technology in Taiwan and related subjects has been taught in human resource management of engineering education. He is also a membe of some professional organizations, like as ASEE, DACC, CVIEA, et al. His research has focused on engineering education, and innovative management.

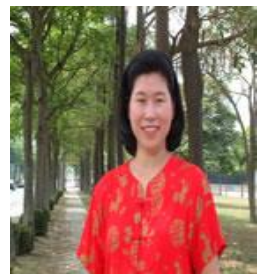

Chun-Mei Chou is a professor \& chair at Graduate School of Technological and Vocational Education at National Yunlin University of Science \& Technolog, Yunlin, Taiwan. Her research interest include the business education and human development oriented technological and vocational school. 